\title{
大麦 $\beta$-グルカンの機能性について
}

\author{
青江誠一郎
}

(大妻女子大学家政学部)

\section{Physiological function of $\beta$-glucan in barley}

\author{
Seiichiro Aoe \\ Department of Food Science, Faculty of Home Economics, Otsuma Women's University, \\ 12, Sanbancho Chiyoda-ku, Tokyo, 102-8357 \\ 干102-8357＼cjkstart東京都千代田区三番町12
}

\begin{abstract}
Barley have a component of soluble fiber called $\beta$-glucan which have $\beta-(1 \rightarrow 3)$ and $\beta$-(1 $\rightarrow 4)$-linkages. Studies on the physiological functions of barley have been rapidly increasing in terms of the cholesterol-lowering effect, serum glucose and insulin normalization including the second meal effects, decreased body fat accumulation, and appetite control. It has been scientifically proven that the soluble dietary fiber in barley, $\beta$-glucan, might reduce the risk of cardiovascular disease (CVD). The Food and Drug Administration (FDA) has stated that daily intakes of $3 \mathrm{~g}$ or more of soluble fiber ( $\beta$-glucan) in barley may reduce the risk of heart disease by its ability to lower total cholesterol and LDL-cholesterol. The European Food Safety Authority (EFSA) supported the following health claim for barley $\beta$-glucan: 1) maintenance of normal blood LDL-cholesterol concentrations, 2) reduction of post-prandial glycemic responses, and 3) digestive function (normal stool frequency). Recent clinical studies have suggested that the consumption of barley and its products might reduce many risk factors associated with the metabolic syndrome, namely diabetes and dyslipidemia. In our intervention study in Japanese men and women, the consumption of high $\beta$ glucan barley reduced waist circumstaznce and visceral fat area. This review presents recent information about the health function of barley $\beta$-glucan.
\end{abstract}

\section{1.はじめに}

日本において，食物繊維は「ヒトの消化酵素によって 消化されない食物中の難消化性成分の総体」と定義され ている。この定義によれば, 難消化性オリゴ糖や糖アル コールも含まれることになるが, 食品成分表や食事摂取 基準に用いられている食物繊維は，プロスキー変法（酵 素-重量法)を用いて定量されるものに限られる。一方で, 栄養表示基準に用いられている食物繊維はプロスキー変 法（酵素一重量法）または高速液体クロマトグラフ法（酵 素-HPLC 法）を用いることができるため, 低分子（3 糖類以上）の難消化性成分も含まれることになる。

日本人の食物繊維の 1 日平均摂取量は, 1955年では $22 \mathrm{~g}$ だったが, 現在は $15 \mathrm{~g}$ を下回っている(図 1) ${ }^{1)} 。$ 日本人の食事摂取基準（2010年版）では，1日の食物繊
維の目標量は男性が $19 \mathrm{~g}$ ，女性が17 $\mathrm{g}$ であるが，20～30 歳代の男性は13〜 $14 \mathrm{~g}$, 女性は12〜13 g 程度の摂取量で 若い世代で摂取量が少ない。特に穀類からの食物繊維の 摂取が年々低下しており，2012年では1955年の約半分で ある2)。これは，米離れとともに，大麦などの雑穀が食 べられなくなったことも一因である。新たな日本人の食 事摂取基準（2015年版）では，18～69歳の男女とも目標 量が $1 \mathrm{~g}$ ずつ増えるのでさらに対策が必要である。した がって, かつてのレベルまで食物繊維摂取量を戻すため には，穀類の摂取量を増やすことが一つの方法である。 特に麦ご飯は，手軽で効率的に食物繊維が摂取できる。

\section{2. 穀物の機能性研究の現状}

食物繊維の給源として穀物の役割は重要で, 海外の食 事ガイドラインでは朝食に全粒穀物や穀物繊維に富む食 




図 1 日本人の食物繊維摂取量の変化

池上幸江 ${ }^{1)}$ のデー夕に2000年度以降の国民健康・栄養調查結果を著者が追加したものを引用

事を推奨している。今年になって, 朝食に穀物を撖取す る利点についてシステマティックレビューが報告され た ${ }^{3)}$ このレビューによれば, 全粒穀物や高穀物瀻維食は, 2 型糖尿病のリスク低減, 過体重や肥満のリスク低減 （grade B：おおむね信頼性の高いエビデンスあり）と関 係し，さらにオーツ，大麦を含むシリアル食品は，血中 コレステロール濃度を低下させる（grade A：信頼性の 高いエビデンスあり）と評価された。

これまで，食物纎維の肥満， 2 型糖尿病，冠状動脈疾 患のリスク低減への作用は，不溶性食物繊維よりも水溶 性食物瀻維の寄与が大きいと考えられてきた。水溶性食 物瀻維は，胃内や小腸内での作用により血糖応答やコレ ステロール・胆汁酸代謝を生理的に調整する。しかしな がら，大麦，オート麦，ライ麦を除く穀物瀻維は，不溶 性食物纎維が主体であり，システマティックレビューの 結果を水溶性食物繊維の効果とすることはできない。シ ステマティックレビューの問題点として, 食物瀻維の特 性に関する詳細な説明が不十分であることが挙げられる。

\section{3．大麦中の食物繊維}

精白米は，食物繊維含量が少なく，玄米でもほとんど が不溶性食物繊維である。一方，大麦は精麦しても食物 瀻維量が減少することなく，他の穀物に比べて水溶性食 物瀻維含量が多い。大麦とオート麦の水溶性食物瀻維の 大部分が $\beta$ - $(1 \rightarrow 3)(1 \rightarrow 4)-\mathrm{D}-$ グルカンである。また, 大麦は, オート麦よりもアラビノキシランの比率が高い ことも特徴である。近年， $\beta$-グルカンを高含有する大 麦の品種が育種され，さらに麦ご飯に適したモ千種の大 麦品種が栽培されるようになった。

\section{4. 大麦の健康強調表示の動向}

表 1 に大麦の各国に打ける健康强調表示を示す。アメ リカ食品医薬品局（FDA）は世界に先駆けて疾病リスク 低減表示を認め, 大麦については，2006年にこれまでに 認められていた「特定食品の水溶性食物瀻維と冠状動脈 疾患」の中に追加された。カナダでは，大麦について 2012年に健康表示を認めている。欧州食品安全機関 （EFSA）では，大麦について健康表示 3 項目の表示を認 めた。その他，オーストラリアやニュージーランドに扔 いても2013年に健康表示がされた。

また，日本に抢いては，2013年に食品の機能性評価事 業を進めている公益財団法人日本健康・栄養食品協会が, 大麦由来 $\beta$-グルカンの「血中コレステロール正常化」, 「食後血糖值の上昇抑制」「満腹感の維持」作用について, いずれも「機能性について肯定的な根拠がある」と認め だ)。

\section{5. 大麦 $\beta$-グルカンの機能性}

\section{（1）血中コレステロール濃度の正常化}

米国人において，血清コレステロール濃度を低下させ る量は， $\beta$-グルカンとして $3 \mathrm{~g}$ 以上と報告されている ${ }^{5)}$ 筆者らは， $\beta$-グルカンを高含有する大麦を用いて，血 清総コレステロール濃度が高い日本人被験者を対象に介 入試験を行った。50\%大麦を配合したパック麦ご飯を主 食として，1日に 2 パック，12週間每日摂取する試験を 行った（ $\beta$ ーグルカン $3.5 \mathrm{~g} /$ パック）。その結果，血清総， LDL-コレステロール濃度が有意に低下した。これらの 研究から, 日本人の食生活に拀いても大麦の摂取が血中 コレステロール濃度低下に有効であることが確認され $た^{6)}$ 
大麦 $\beta$-グルカンの機能性について

表 1 大麦の各国における健康強調表示

\begin{tabular}{|c|c|c|c|c|}
\hline 国 名 & 評価年 & 関与成分 & 表示許可内容 & 必要量 \\
\hline 米国 & 2005 & 同上 & 同上 & 同上 \\
\hline カナダ & 2012 & 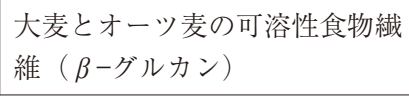 & 冠状動脈心疾患のリスク低減 & $\begin{array}{l}1 \text { 食あたり } 0.75 \mathrm{~g} \\
\text { 以上（1日 } 3 \mathrm{~g} ）\end{array}$ \\
\hline \multirow[t]{3}{*}{ 欧州連合 } & \multirow[t]{3}{*}{$\begin{array}{l}2010 \\
2011\end{array}$} & 大麦 $\beta$-グルカン & $\begin{array}{l}\text { コレステロール低下による心臓 } \\
\text { 疾患のリスク低減 }\end{array}$ & 1 日 $3 \mathrm{~g}$ 以上 \\
\hline & & 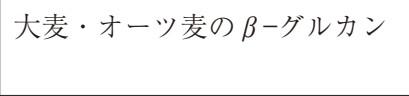 & 食後血糖値の上昇抑制 & $\begin{array}{l}1 \text { 食中の糖質 } 30 \mathrm{~g} \\
\text { あたり } 4 \mathrm{~g} \text { 以上 }\end{array}$ \\
\hline & & $\begin{array}{l}\beta \text {-グルカンを含む大麦・オー } \\
\text { ツ麦由来の食物繊維 }\end{array}$ & 排便促進効果 & 1 日 $3 \mathrm{~g}$ 以上 \\
\hline $\begin{array}{l}\text { オーストラリア・ } \\
\text { ニュージーランド }\end{array}$ & 2013 & 大麦・オーツ麦の $\beta$-グルカン & コレステロール低下 & $\begin{array}{l}1 \text { 食あたり } \beta \text {-グ } \\
\text { ルカン } 1 \mathrm{~g} \text { 以上 }\end{array}$ \\
\hline
\end{tabular}

腹囲の変化量



内臓脂肪面積変化量

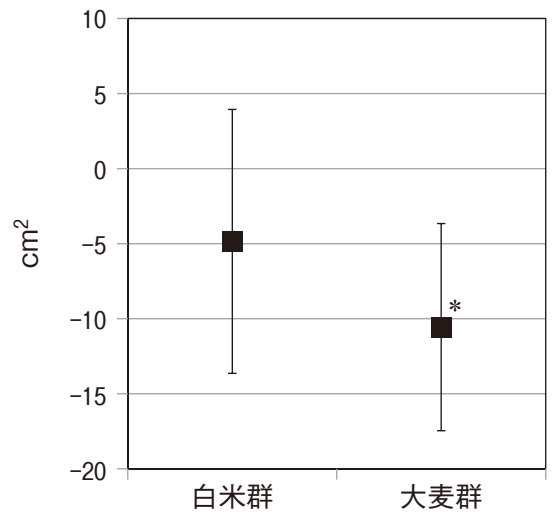

図 2 日本人を対象とした大麦摂取試験における摂取前から摂取12週後

(エンドポイント時点) までの胴回りと内臓脂肪面積の変化量 ${ }^{11}$

平均值と $95 \%$ 信頼区間を表す。

$*$ 摂取前 vs 摂取後 $(p<0.05)$

\section{（2）食後の血糖上昇抑制}

大麦の摂取は，食後の血糖上昇を抑制して，インスリ ンの過剩分泌を抑える効果が多く報告されている 7.8 。 本効果は, 可食部 (胚乳部) に存在する $\beta$-グルカンが 大麦中およびその他のデンプンの消化吸収を穏やかにす る効果によるものと考えられる。血糖応答曲線下面積も 大麦添加により小さくなるので，大麦の配合により GI （Glycemic Index）を低隇することができる。

\section{（3）満腹感の持続とエネルギー摂取量の調節}

大麦を配合した食品は，胃内滞留時間が長くなるため， 満腹感が持続する。さらに, 大麦 $\beta$-グルカンは, 消化 管ホルモンの分泌に影響を与え, 満腹感の持続に作用し, 食事のエネルギー摂取量を低減させるといわれている。 「満腹感の持続」の内訳として, 食欲の抑制, 満腹感の 増強, 空腹感の減少効果が報告されている。また, 朝の 食事が昼の食事の血糖応答や空腹感に影響するというセ カンドミール効果が注目されている。日本人に捛いても 朝食あるいは昼食に大麦を含む食事をとることで次の食
事の食欲や糖代謝に効果が期待できる可能性が近年報告 されている9)。さらに，セカンドミール時に血中 GLP1 濃度の上昇が報告され，大麦 $\beta$-グルカンがセカンド ミール効果の要因となっている可能性がある ${ }^{10)}$ 。

\section{（4）内臓脂肪蓄積抑制}

これまでメタボリックシンドロームの原因である内臓 脂肪蓄積に対する大麦の作用について, 日本人を対象と した研究はなかった。筆者らのグループの試験では，高 コレステロール血症男性に 12 週間, $\beta$-グルカン高含有 大麦と白米 $1 ： 1$ の麦飯を 1 日 2 パック（320 g/日）摂 取させたところ, 腹囲と内臟脂肪面積が有意に低下し た7)。皮下脂肪より内臟脂肪が減少したことから, メ夕 ボリックシンドローム改善に有効であることが期待され るという，日本人でははじめての知見が得られた。さら に, BMI 25 以上の成人男女50名を対象に, 白米パックラ イス 1 日 2 食または $30 \%$ も麦配合パックライス 1 日 2 食（ $\beta$-グルカン: $2.8 \mathrm{~g} /$ 日）を 12 週間摂取する試験 を行った ${ }^{11}$ 。その結果, 腹囲と内臓脂肪面積が有意に低 
下した（図 2 )。したがって，日本人において内臓脂肪 低減効果を発揮する有効摂取量は， $\beta$-グルカンとして 1 日あたり約 $3 \mathrm{~g}$ であると推定した。これは, 血清コレ ステロールを正常化する摂取量と同じ量である。

\section{6. 大麦の食品への利用}

大麦の食品への利用は，粒として食べる食品と大麦粉 を加工した食品がある。前者は，モチ種の大麦が育種さ れたため，麦ご飯としてお弁当，おにぎりにも利用され るようになった。モチ種には，アントシアニジンを含ま ない品種があり，ご飯に配合しても気にならない大麦も 開発された。また，その食感からサラダなどに利用する 食品も開発されている。一方, 後者は, 高 $\beta$-グルカン 大麦粉が開発され，パン，麺，菓子などに利用されてい る。筆者らは, 大麦 $\beta$-グルカン $1 \mathrm{~g}$ 含有クラッカーの 摂取により食後血糖の上昇を抑制できることを報告し た ${ }^{12)}$ 。

\section{7.おわりに}

筆者らの研究結果は，日本人においても大麦摂取の有 効性を裏付けた結果となった。また，大麦は実験動物に おいて脂質代謝改善作用に加え, 脂肪組織重量や脂肪細 胞のサイズに影響を与えることを見出した。さらにこ れまで考えられてきた食物繊維の消化管内での直接的な 作用のほかにも機能が存在する可能性を見出している。 大麦 $\beta$-グルカンのどのような特性が機能発現に寄与し ているのかが今後の研究課題である。

\section{文献}

1）池上幸江：日本人の食物瀻維摂取量の変遷, 日本食物繊 維研究会誌，1，3-12（1997）

2 ) 厚生労働省健康局がん対策 ·健康増進課：平成24年国民
健康・栄養調査結果の概要 (2014)

3 ) Williams PG: The benefits of breakfast cereal consumption: a systematic review of the evidence base, Adv Nutr, 5, 636S673S (2014)

4）日本健康 - 栄養食品協会：平成24年度「食品の機能性評 価事業」結果報告, http://www.jhnfa.org/topic146-1.pdf (2015 年 3 月 10 日)

5 ) Ripsin CM, Keenan JM, Jacobs DR, et al:: Oat products and lipid lowering. A meta-analysis, JAMA, 267, 3317-3325 (1992)

6 ) Shimizu C, Kihara M, Aoe S, Araki S, Ito K, Hayashi K, Watari J, Sakata Y, Ikegami S: Effect of high beta-glucan barley on serum cholesterol concentrations and visceral fat area in Japanese men -a randomized, double-blinded, placebocontrolled trial, Plant Foods Hum Nutr, 63, 21-5 (2008)

7 ) Liljeberg HG, Granfeldt YE, Björck IM; Products based on a high fiber barley genotype, but not on common barley or oats, lower postprandial glucose and insulin responses in healthy humans, J Nutr, 126, 458-466 (1996)

8 ) Behall KM, Scholfield DJ, Hallfrisch J: Comparison of hormone and glucose responses of overweight women to barley and oats, J Am Coll Nutr, 24, 182-188 (2005)

9）福原育夫，池永武，野口洋樹，小梯知英子，小長井里織 前佛佳菜子, 富田晋平, 甲田哲之： $\beta$-グルカン高含有大麦 混合米飯の食後血糖応答とそのセカンドミール効果に及ぼ す影響，薬理と治療，41，789-795（2013）

10) Johansson EV, Nilsson AC, Östman EM, Björck IME: Effects of indigestible carbohydrates in barley on glucose metabolism, appetite and voluntary food intake over $16 \mathrm{~h}$ in healthy adults, Nutrition J, 12, 46 (2013)

11）松岡翼, 内松大輔, 小林敏樹, 青江誠一郎：大麦食が過 体重日本人男女のメタボリックシンドローム関連指標に及 ぼす影響，ルミナコイド研究，18，1825-33（2014）

12）青江誠一郎，野口洋樹，池永武，小梯知英子，角元慶二 甲田哲之：健常成人に拉ける大麦 $\beta$-グルカン $1 \mathrm{~g}$ 含有ク ラッカーの食後血糖応答に及ぼす影響—無作為化二重盲検 プラセボ対照クロスオーバー比較試験一, 薬理と治療, 42, 687-693 (2014)

本稿は，第49回研究集会における発題講演をまとめたものである。 